\title{
MODULATION OF
}

METHYLENETETRAHYDROFOLATE

REDUCTASE ACTIVITY BY

S-ADENOSYLMETHIONINE AND

BY DIHYDROFOLATE ANDITS

POLYGLUTAMATE ANALOGUES

ROWENA G MATTHEWS and S COLETTE DAUBNER

The Department of Biological Chemistry and The Biophysics Research Division,

The University of Michigan. Ann Arbor, Michigan 48109

INTRODUCTION

Methylenetetrahydrofolate reductase (EC 1.1.99.15) catalyzes the reduction of methylenetetrahydrofolate to methyltetrahydrofolate [equation 1]

$\mathrm{NADPH}+\mathrm{H}^{+}+\mathrm{CH}_{2}-\mathrm{H}_{4}$ folate $\longrightarrow \mathrm{NADP}+\mathrm{CH}_{3}-\mathrm{H}_{4}$ folate

This overall reaction is effectively irreversible in vivo (1) and commits one carbon units to the pathways of adenosylmethıonine-dependent methylation in mammalian cells. As shown in Figure 1, methylenetetrahydrofolate reductase is located at a branch point in folate metabolism, and can be viewed as competıng for tetrahydrofolate-bound one carbon units with thymidylate synthase (EC 2.1.1.45) and with the AICAR* and GAR transformylases (EC 2.1.2.3; EC 2.1.2.2) which catalyze the incorporation of one carbon units into the nascent purine ring system. We have been interested in studying the regulation of flux at this branch point, which has important implications for our understandıng of folate metabolism in both normal and neoplastic cells

Mammalian methylenetetrahydrofolate reductase activity was first ident1fied by Donaldson and Keresztesy (2), who showed that FAD was required for maxımal activity. The enzyme was purified about 500 -fold from pig and rat liver by Kutzbach and Stokstad (3). They demonstrated that the enzyme was inhibited by AdoMet and that the inhibition could be reversed by adenosylhomocysteine, and they provided evidence that these effectors were bound at an allosteric site on the enzyme Thus regulation of methylenetetra-

*Abbreviations used are AICAR, 5'-phosphorıbosyl-5-amıno-4-ımıdazolecarboxamıde, GAR, glycineamide ribonucleotıde, $\mathrm{CH}_{3}-\mathrm{H}_{4}$ folate, methyltetrahydrofolate, $\mathrm{CH}_{2}-\mathrm{H}_{4}$ folate, methylenetetrahydrofolate, $\mathrm{CH}_{2}-\mathrm{H}_{4} \mathrm{PteGlu}$, methylenetetrahydropteroyl-polyglutamate with $\mathrm{n}$ glutamyl residues, $\mathbf{H}_{2} \mathrm{PteGlu}_{\mathrm{n}}$, dihydropteroylpolyglutamate with $\mathrm{n}$ glutamyl residues, AdoMet, adenosylmethıonıne 


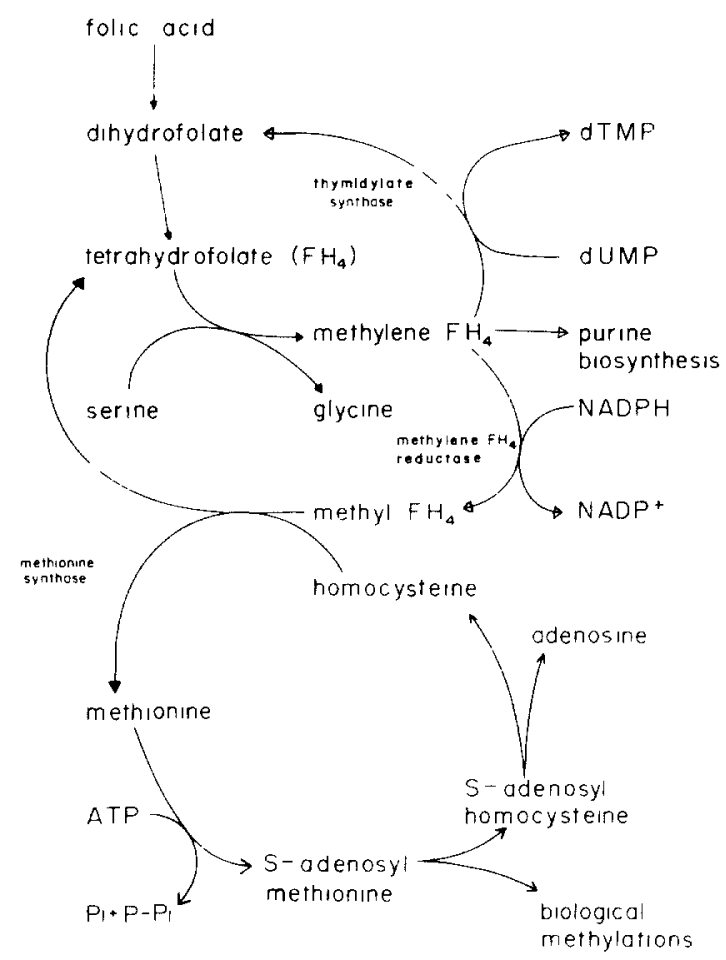

FIG I Pathways of mammalian folate metabolısm

hydrofolate reductase activity appeared to conform to the pattern of feedback inhibition by the final common product of a reaction pathway

Regulation of methylenetetrahydrofolate reductase activity by the AdoMet/adenosylhomocysteıne ratio is responsive only to the demands for one carbon units imposed by AdoMet-dependent biological methylations, and not to demands of the competıng pathways of thymidylate and purine biosynthesis Thus, a prori, one might expect that methylenetetrahydrofolate reductase activity would also be modulated by cellular requirements for de novo biosynthesis of purines and pyrimidines as well as by cellular levels of Ado Met

We have now purified pig liver methylenetetrahydrofolate reductase to homogeneity and demonstrated that the enzyme contains non-covalently bound FAD as a prosthetic group $(4,5)$. In this paper we shall review our studies on the inhibition of the enzyme by dihydrofolate and its polyglutamate analogues $(6,7)$ and report the results of more recent studies on the modulation of enzymatic activity by AdoMet 


\section{MATERIALS AND METHODS}

Homogeneous pıg liver methylenetetrahydrofolate reductase was prepared as described by Daubner and Matthews (4,5) and was used for studies of AdoMet inhibition Ado Met was purchased from Sigma or from BoehringerMannheım (both sources isolate Ado Met from yeast so that the metabolite is the natural stereossomer both at the $\alpha$-carbon of methionine and at the sulfonium pole). The purchased AdoMet was further purified by high performance liquid chromatography on an Altex Ultrasphere ODS column (8). Adenosylhomocysteıne was purchased from Sigma and used without further purification For measurements of the effects of AdoMet and/or adenosylhomocysteine on methylenetetrahydrofolate reductase actıvity, the assay methods used were those described previously $(5,6)$ except that all assays were performed in $50 \mathrm{~mm}$ potassium phosphate buffer, $\mathrm{pH} \mathrm{6.7,} \mathrm{containıng} 2 \mu \mathrm{M}$ FAD For measurements of NADPH-menadione or NADPH- $\mathrm{CH}_{2}-\mathrm{H}_{4}$ folate oxidoreductase activities in the presence of AdoMet or adenosylhomocysteine, the enzyme and buffer and any AdoMet or adenosylhomocysteine were preincubated in the assay cuvette for $10 \mathrm{~min}$ at $25^{\circ}$ and then substrates were added to start the reaction For $\mathrm{CH}_{3}-\mathrm{H}_{4}$ folate-menadione oxidoreductase assays the enzyme was preincubated with AdoMet and then diluted into an assay mixture containing the same concentration of AdoMet. Assays were teminated after incubation for $8 \mathrm{~m} ı$ at $25^{\circ}$

\section{RESULTS AND DISCUSSION}

\section{Inhibution of Methvlenetetrahydrofolate Reductase by Dihydropteroylpolyglutamates}

Methylenetetrahydrofolate reductase exhıbıts parallel line kınetıcs during catalysis of NADPH-CH$-\mathrm{CH}_{4}$ folate oxidoreduction. Dihydrofolate is an inhibitor of the reaction and is competitive with respect to $\mathrm{CH}_{2}-\mathrm{H}_{4} \mathrm{Pte}$ Glu and uncompetitive with respect to NADPH. Dihydrofolate is a more potent inhibitor than similar concentrations of the natural stereossomers of tetrahydrofolate, methyltetrahydrofolate, folic acıd or methenyltetrahydrofolate (6). The $\mathrm{K}_{1}$ values for inhibition of $\mathrm{NADPH}-\mathrm{CH}_{2}-\mathrm{H}_{4} \mathrm{PteGlu}_{1}$ oxidoreductase activity by $\mathrm{H}_{2} \mathrm{PteGlu}_{\mathrm{n}}$ derivatives with one to seven glutamyl residues have been measured (7) and are shown in Figure 2 In all cases the observed inhibitıon was linearly competitıve with respect to $\mathrm{CH}_{2}-\mathrm{H}_{4} \mathrm{PteGlu}_{1}$. The $K_{1}$ values decreased from $65 \mu \mathrm{M}$ for $\mathrm{H}_{2}$ PteGlu $_{1}$ to $0.013 \mu \mathrm{M}$ for $\mathrm{H}_{2} \mathrm{PteGlu}_{6}$, and then increased to $0.065 \mu \mathrm{M}$ for $\mathrm{H}_{2} \mathrm{PteGlu}_{7}$. These data indicate a free energy decrease of $0.75 \mathrm{kcal}$ per glutamyl residue associated with the binding of the five terminal residues of $\mathrm{H}_{2} \mathrm{PteGlu}_{6}$. Methylenetetrahydropteroylpolyglutamates are substrates for methylenetetrahydrofolate reductase and show increased values for $\mathrm{k}_{\text {cat }} / \mathrm{K}_{\mathrm{CH}_{2}-\mathrm{H}_{4} \mathrm{PteGl}_{\mathrm{n}}}$ relative to the monoglutamate 


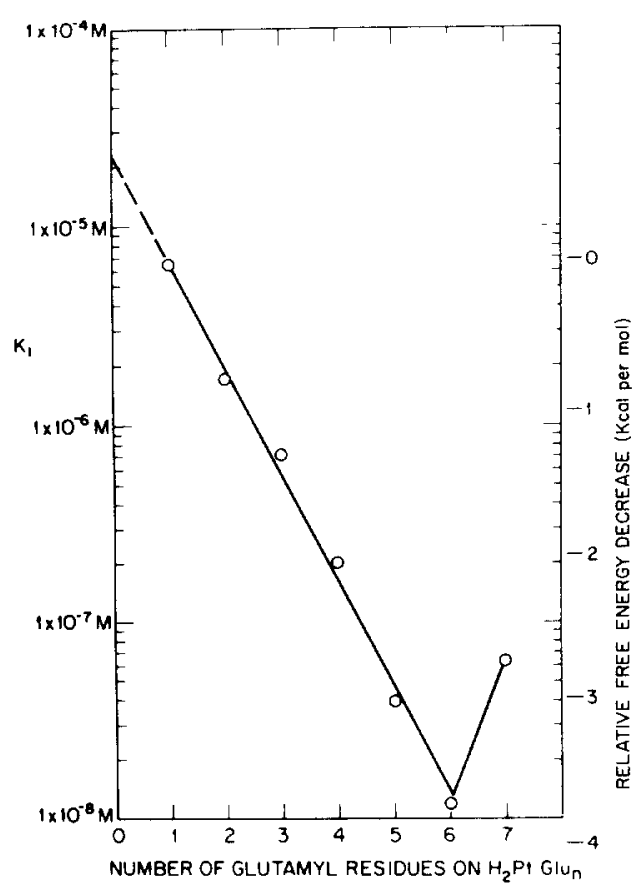

FIG 2 Variatıon of the $K_{1}$ values for dihydropteroylpolyglutamate inhibitors with the number of glutamyl residues Individual $\mathrm{K}_{1}$ values were determined for the $\mathrm{NADPH}-\mathrm{CH}_{2}-\mathrm{H}_{4} \mathrm{PteGlu}_{1}$ oxidoreductase assay as described in reference (7) The $\mathrm{K}_{1}$ values represent dissociation constants for the interaction of $\mathrm{H}_{2}$ PteGlu $_{n}$ with that enzyme form which is binding the inhibitor, and are thus measures of the free energy decrease associated with binding of inhibitor to enzyme On the right hand border of the figure are shown the free energy decreases corresponding to each $K_{1}$ value

substrate, with the maximum $k_{\text {cit }} / K_{m}$ value being observed for the hexaglutamyl substrate (Table 1)

Intracellular $\mathrm{CH}_{2}-\mathrm{H}_{4} \mathrm{PteGlu}_{\mathrm{n}}$ is present mainly as the hexaglutamate in pig liver (9) and although the concentration of this metabolite has not been determined it is probably in the range from 05 to $5 \mu \mathrm{M}$ in the interphase cell Thus, the free energy decrease associated with the binding of the polygluta myl side chain of $\mathrm{CH}_{2}-\mathrm{H}_{4} \mathrm{PteGlu}_{6}$ is used to lower the $\mathrm{K}_{\mathrm{m}}$ for this substrate well below the probable concentration of this metabolite in the cell While we have no information on the polyglutamyl chain length of $\mathrm{H}_{2} \mathrm{PteGlu}_{n}$ in pıg liver, we may perhaps assume that this too is largely present as the hexaglutamyl derivative, since it is generated primarily, if not exclusively, from $\mathrm{CH}_{2}-\mathrm{H}_{4} \mathrm{PteGlu}$ by the action of thymidylate synthase The cellular concentration of $\mathrm{H}_{2} \mathrm{PteGlu}_{\mathrm{n}}$ is too low to measure $(<\mathrm{I} \mu \mathrm{M})$. Its concentration in cells has been estımated from the rate of thymidylate incorporation into DNA and 
TABLE I KINETIC PARAMETERS ASSOCIATED WITH NADPH-CH ${ }_{2}-\mathrm{H}_{4}$ PteGlu $_{n}$ OXIDOREDUCTION

\begin{tabular}{|c|c|c|c|c|}
\hline Substrate & $\underset{(\mathrm{min})^{-1}}{\mathbf{k}_{\mathrm{cat}}}$ & $\begin{array}{c}\mathrm{K}_{\mathrm{CH}_{2}-\mathrm{H}_{4} \mathrm{Ptc}\left(\mathrm{l} \mathrm{u}_{\mathrm{n}}\right.} \\
(\mu \mathrm{M})\end{array}$ & $\underset{(\mu \mathrm{M})}{\mathrm{K}_{\mathrm{NADPH}}}$ & $\begin{array}{c}\mathrm{k}_{\text {cat }} / \mathbf{K}_{\left.\mathrm{CH}_{2}-\mathrm{H}_{4} \mathrm{PteG}\right] \mathrm{u}_{\mathrm{n}}} \\
(\mu \mathrm{M}) \\
(\mathrm{min})\end{array}$ \\
\hline $\mathrm{CH}_{2}-\mathrm{H}_{4} \mathrm{PteGlu}_{1}$ & 1600 & 71 & 16 & 225 \\
\hline $\mathrm{CH}_{2}-\mathrm{H}_{4}^{4} \mathrm{PteGlu}$ & 2820 & 52 & - & 542 \\
\hline $\mathrm{CH}_{2}-\mathrm{H}_{4} \mathrm{PteGlu}$ & 2740 & 17 & 15 & 1610 \\
\hline $\mathrm{CH}_{2}-\mathrm{H}_{4}^{4} \mathrm{PteGlu}_{4}$ & 2770 & 062 & 76 & 4470 \\
\hline $\mathrm{CH}_{2}-\mathrm{H}_{4} \mathrm{PteGlu}_{5}$ & 1020 & 026 & 125 & 3920 \\
\hline $\mathrm{CH}_{2}-\mathrm{H}_{4}$ PteGlu 6 & 1090 & 0.10 & 185 & 10900 \\
\hline $\mathrm{CH}_{2}-\mathrm{H}_{4} \mathrm{PteGlu}_{7}$ & 1090 & 0.51 & 176 & 2140 \\
\hline
\end{tabular}

from the concentration and kınetıc parameters of dıhydrofolate reductase in these cells. The estimated value obtained by Jackson and Harrap was 0.02-0.06 $\mu \mathrm{M}(10)$ while the data of White and Goldman (11) suggest steady state concentrations in the range of $2-5 \mathrm{~nm}$ (Courtland White, personal communication). Values estimated in this manner are based on mean values of the rate of thymidylate incorporation into DNA for an entıre population of logarithmically growing cells. Since only a small portion of the cells are actually synthesizing DNA at any given time, these values probably underestımate the rate of thymidylate biosynthesis during DNA synthesis. At present, we do not have sufficiently accurate data to assess the quantitative significance of $\mathbf{H}_{2}$ PteGlu $_{6}$ inhıbition of methylenetetrahydrofolate reductase.

We have demonstrated that the actıvitıes of thymidylate synthase, methylenetetrahydrofolate reductase and methionine synthase are all associated with the cytoplasmic fraction of rat liver cells (Figure 3 ). In the case of thymidylate synthase, this is true whether the act ivity is measured in normal adult rat liver or $24 \mathrm{hr}$ after partial hepatectomy, where thymidylate synthase activity is increased about 10-fold. Studies of Werkheiser (12) have shown that dihydrofolate reductase activity is also associated with the cytoplasmic fraction of rat liver cells Thus, in the rat, there is no evidence for differential metabolic compartmentation of thymidylate synthase, dihydrotolate reductase and methylenetetrahydrofolate reductase activities

As the data in Table 2 show, the methylenetetrahydrofolate reductase reaction velocity should be extremely sensitive to variations in the ratio of $\mathrm{CH}_{2}-\mathrm{H}_{4}$ PteGlu $_{6}$ to $\mathrm{H}_{2}$ PteGlu $_{6}$ in cells The $\mathrm{K}_{\mathrm{m}}$ of dihydrofolate reductase for its dihydropteroylpolyglutamate substrates lies between $0 \mathrm{I}$ and $5 \mu \mathrm{M}$, depending on the source of the mammalian dihydrofolate reductase and on the conditions under which the $K_{m}$ values are measured $(13,14)$ In general, the $K_{m}$ of the mammalian enzyme for $\mathrm{H}_{2}$ PteGlu $_{n}$ derivatives is rather independent of the number of glutamyl residues (14) Since $\mathrm{H}_{2}$ PteGlu levels in the cell are generally lower than the $\mathrm{K}_{\mathrm{m}}$ for this enzyme, elevations in the 


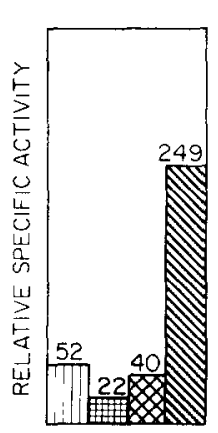

Loctate dehydrogenose

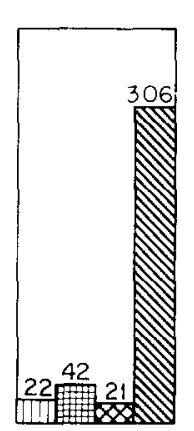

Thymıdylate synthase

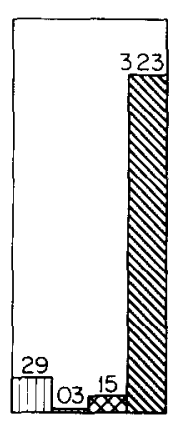

Methylene tetrahydrofolate reductase

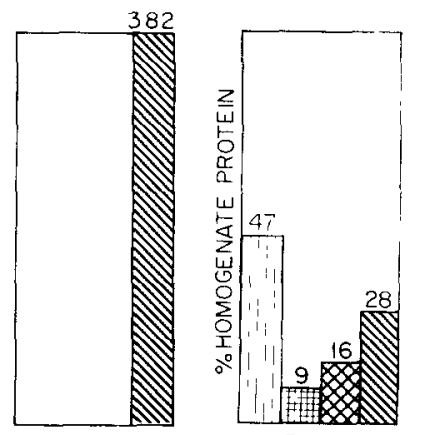

Methionine Protein synthase

FIG 3 Cellular compartmentation of methylenetetrahydrololate reductase, methionine synthase and thymidylate synthase from rat liver Adult male Sprague-Dawley rats were lasted for $24 \mathrm{hr}$ prior to sacrifice The livers were excised and subjected to cellular fractionation as described by Hogeboom (16) Particulate fractions were solubilized by soncation in the presence of $005^{\circ}$, Triton X-100 and $05 \%, 2$-mercaptoethanol From left to right are shown the relatue specific detivities of the nuclear, mitochondrial, microsomal and cytoplasmic fractions The enzyme disays used have been prevously described thymidylate synthase (17), methylenetetrahydrofoldte reductase (6), methionıne synthase (18) and lactate dehydrogenase (19) The data shown here for thymidylate synthase were obtained using rat livers removed $24 \mathrm{hr}$ after partial hepatectomy, but simılar results were obtained from normal adult rat liver The protein content of the cell fractions was determined usıng Bı-Rad protein assay mix and bovine serum albumin as the protein standard The results shown here represent the averages of 3 separate cell fractionation studies

TABLE 2 VALUES OF $i_{50}$ FOR $\mathrm{H}_{2}$ PteGlu INHIBITION OF $\mathrm{CH}_{2}-\mathrm{H}_{4}$ PteGlun $_{n}$ REDUCTION

\begin{tabular}{|c|c|c|}
\hline Inhibitor substrate & $\begin{array}{c}\mathrm{I}_{50} \text { at } 5 \mu \mathrm{M} \\
\text { substrate }(\mu \mathrm{M})\end{array}$ & $\begin{array}{c}\mathrm{I}_{50} \text { at } 05 \mu \mathrm{M} \\
\text { substrate }(\mu \mathrm{M})\end{array}$ \\
\hline $\begin{array}{l:c}\mathrm{H}_{2} \text { PteGlu }_{1} / \mathrm{CH}_{2}-\mathrm{H}_{4} \text { PteGlu } \\
\mathrm{H}_{2} \text { PteGlu }_{2} & \mathrm{CH}_{2}-\mathrm{H}_{4} \text { PteGlu }_{2} \\
\mathrm{H}_{2} \text { PteGlu }_{3} & \mathrm{CH}_{2}-\mathrm{H}_{4} \text { PteGlu }_{3} \\
\mathrm{H}_{2} \text { PteGlu } & \mathrm{CH}_{2}-\mathrm{H}_{4} \text { PteGlu }_{4} \\
\mathrm{H}_{2} \text { PteGlu }_{5} & \mathrm{CH}_{2}-\mathrm{H}_{4} \text { PteGlu }_{5} \\
\mathrm{H}_{2} \text { PteGlu } & \mathrm{CH}_{2}-\mathrm{H}_{4} \text { PteGlu } \\
\mathrm{H}_{2} \text { PteGlu } & \mathrm{CH}_{2}-\mathrm{H}_{4} \text { PteGlu }\end{array}$ & 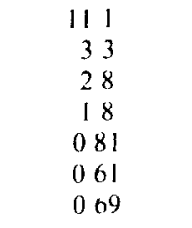 & $\begin{array}{ll}6 & 95 \\
1 & 85 \\
0 & 89 \\
0 & 36 \\
0 & 11 \\
0 & 07 \\
0 & 13\end{array}$ \\
\hline
\end{tabular}

rate of thymidylate brosynthesis will produce elevated steady state levels of dihydrofolate We suggest that the consequent decredse in the $\mathrm{CH}_{2}-\mathrm{H}_{4}$ folate $\mathrm{H}_{2}$ folate ratio will lead to inhibition of methylenetetrahydrofolate reductase, sparing $\mathrm{CH}_{2}-\mathrm{H}_{4}$ folate for purıne and pyrimidine biosynthesis Certainly, methylenetetrahydrofolate reductase activity will be decreased in cells which have been exposed to methotrexate, where the $\mathrm{H}_{2}$ folate concentration may approach $20 \mu \mathrm{M}$ (II) 
Inhibition of Methylenetetrahydrofolate Reductase by Adenosilmethionine

We have investigated the inhibition of methylenetetrahydrofolate reductase activity by AdoMet by measuring three different activities of the enzyme.

$$
\begin{aligned}
& \mathrm{NADPH}+\text { Menadione } \longrightarrow \mathrm{NADP}^{+}+\text {Menadiol } \\
& \mathrm{NADPH}+\mathrm{H}^{+}+\mathrm{CH}_{2}-\mathrm{H}_{4} \text { folate } \longrightarrow \mathrm{NADP}^{+}+\mathrm{CH}_{3}-\mathrm{H}_{4} \text { folate } \\
& \mathrm{CH}_{3}-\mathrm{H}_{4} \text { folate }+ \text { Menadione } \longrightarrow \mathrm{CH}_{2}-\mathrm{H}_{4} \text { folate }+ \text { Menadiol }
\end{aligned}
$$

If these reactions are all studied under the same conditions, $v i z$. in $50 \mathrm{~mm}$ phosphate buffer, $\mathrm{pH} 67,25^{\circ}$, AdoMet inhibits all three reactıons

As reported by Kutzbach and Stokstad (3), we find that adenosylhomocystenne reverses the inhibition of the NADPH-menadione oxıdoreductase activity exerted by AdoMet, and we obtain an apparent $K_{D}$ of $3 \mu \mathrm{M}$ for adenosylhomocysteıne. In contrast, methylthioadenosıne $(150 \mu \mathrm{M})$ and methıonine $(560 \mu \mathrm{M})$ neither reverse the inhibition exerted by AdoMet nor have any inhibitory effect themselves The transitions between uninhibited and inhibited forms of the enzyme are slow, as previously observed by Kutzbach and Stokstad (3). Since all assays reported here were performed after a 10-mın preincubation of the enzyme with AdoMet and/or adenosylhomocysteine in the absence of NADPH, we have assumed that the equilibrium between inhibited and uninhibited forms of the enzyme established during preincubation did not change during the tıme required for initial velocity measurements Kınetıcs of this type can not be described by the conventional equations for competitive or noncompetitive inhibition, which assume rapid equilibrium binding of inhibitor and varied substrate to the enzyme Rather, the enzyme behaves in the presence of non-saturating inhibitor as if it were a mixture of two forms of enzyme, not in equilibrium, each of which is described by its own kınetic equation. The proportion of the two forms of enzyme is a function only of $1 ; K_{1}$.

\section{S UM MAR Y}

Methylenetetrahydrofolate reductase catalyzes the reduction of methylenetetrahydrofolate to methyltetrahydrofolate This reaction commits one carbon units to the pathways of adenosylmethionıne-dependent methylation in mammalian cells We have purified the pig liver enzyme to homogeneity and shown that it contains FAD as a non-covalently bound prosthetic group Methylenetetrahydrofolate is not only a substrate for the reductase, but also for thymidylate synthase and for methylenetetrahydrofolate dehydrogenase. The latter reaction leads to utilization of one carbon units in de novo purine biosynthesis. A priort, one might expect that methylenetetrahydrofolate 
reductase activity would be modulated by cellular requirements for de novo biosynthesis of purines and pyrimidines, as well as by cellular levels of adenosylmethionine Methylenetetrahydrofolate reductase is inhibited by dihydrofolate and its polyglutamate analogues The $K_{1}$ is $65 \mu \mathrm{M}$ for dihydrofolate and decreases with each additional glutamyl residue to a minımum value of $0013 \mu \mathrm{M}$ for dihydropteroylhexaglutamate I he $I_{5,}$ for dıhydropteroylhexaglutamate inhibition of reductase actıvity in the presence of $05 \mu \mathrm{M}$ methy lenetet rahydropteroylhexaglutamate is $007 \mu \mathrm{M}$ We propose that stimulation of thymidylate synthase activity (as in the replicating cell) may lead to elevations in the steady state levels of cellular dihydrofolate derivatives and to resultant inhibition of methylenetet rahydrololate reductase activity Thus methylenetetrahydrofolate derivatives would be spared tor purıne and pyrimidıne biosynthesis.

We have also examined the inhibition of methylenetetrahydrofolate reductase by adenosylmethionıne, which serves as an allosteric effector of the enzymatic activity Adenosylmethionine induces a slow transition in the enzyme, and leads to the inhibition of NADPH-menadione. NADPHmethylenetetrahydrofolate and methyltetrahydrofolate-menadione oxidoreductase activitıes

\section{ACKNOWLEDGEMENTS}

This work has been supported in part by Research Grant GM 24908 from the National Institute of General Medical Sciences. RGM is an Established Investigator of the American Heart Association

\section{REFERENCES}

1 H M KATZEN and J M BUCHANAN, Enzymatic synthesis of the methyl group of methionıne VIII Repression-depression, purification and properties of 5,10-methylenetetrahydrofolate reductase from Escherichia coh, $J$ Biol Chem 240, 825-835 (1965)

$2 \mathrm{~K} O$ DONALDSON and J C KERESZTESY, Naturally occurring forms of folic acid 1 "Prefolic A" Preparation of concentrate and enzymatic conversion to citrovorum factor, $J$ Biol Chem 234, 3235-3240 (1959)

3 C KUTZBACH and E L R STOKSTAD, Mammalian methylenetetrahydrofolate reductase Partial purification, properties, and inhibition by S-adenosylmethionine, Biochim Biophis Acta 250, 459-477 (1971)

4 S C DAUBNER and R G MATTHEWS, Purification and properties of methylenetetrahydrofolate reductase from pig liver, pp 165-172 in Flavins and Flavoproteins (V MASSEY and C H WILliams, JR, eds), Elsevier; North Holland, New York (1982)

5 S C DAUBNER and R G MATTHEWS, Purification and properties of methylenetetrahydrofolate reductase from pig liver, $J$ Biol Chem 257, 140-145

6 R G MATTHEWS and B J HAYWOOD, Inhibition of pig liver methylenetetrahydrofolate reductase by dihydrofolate Some mechanistic and regulatory implications. Biochemistry 18, 4845-485! (1979) 
7 R G MATTHEWS and C M BAUGH, Interactions of pig liver methylenetetrahydrofolate reductase with methylenetetrahydropteroylpolyglutamate substrates and with dihydropteroylpolyglutamate inhibitors, Biochemistrv 19, 2040-2045 (1980)

8 S C DAUBNER. E KRAPF and R G MATTHEWS, Interactions of adenosylmethıonine with methylenetetrahydrofolate reductase, in Transmethilation ( $R$ BORCHARDT, R CREVELING and E USDIN, eds) Macmillan, New York (In press)

9 D G PRIEST and M T DOIG, Evaluation of folylpolyglutamates by electrophoretic separation of fluorodeoxyuridylate-thymidylate synt hase-methylenetetrahydrofolate complexes, in Fol, l-and Antifollpolyglutamates (I D GOLDMAN, B CHABNER and J J BERTINO, eds ) Adtances in Experımental Biology, Plenum Press. New York (In press)

10 R C JACKSON and K R HARRAP, Studies with a mathematical model of tolate metabolism. Arch Biochem Biophis 158, 827-841 (1973)

11 J C WHITE and I D GOLDMAN, Methotrexate resistance in an L1210 cell line resulting from increased dihydrofolate reductase, decreased thymidylate synthetase activity and normal membrane transport Computer simulations based on network thermodynamics, $J$ Biol. Chem 256, 5722-5727 (1981)

12 W $C$ WERKHEISER. Specific bindıng of 4-dmıno folic acid analogues by folıc acid reductase, $J$ Biol Chem 236, 888-893 (1961)

13 R C JACKSON, L I HART and K R HARRAP, Intnnsic resistance to methotrexate of cultured mammalian cells in relation to the inhibition kinetics of their dihydrofolate reductases, Cancer Res 36, 1991-1997 (1976)

14 J K COWARD, $K$ N PARAMESWARAN, A R CASHMORE and J R BERTINO, 7,8-Dihydropteroyl olıgo- $\gamma$-L-glutamates Synthesis and kınetic studies with purified dihydrofolate reductase from mammalian sources, Biochemistry 13, 3899-3903 (1974)

15 I H SEGEL, Enzıme Kineits, Wiley, New York (1975)

16 G H HOGEBOOM, Fractionation of cell components of anımal tissues, pp 16-19 in Methods in Enzumologi, 1, (S P COLOWICK and N O KAPLAN, eds ), Academic Press, New York (1955)

17 S T ROODMAN and G R GREENBERG, A temperature-sensitive thr mutant blocked in the synthesis of thymidylate synthetase, $J$ Biol Chem 246, 2609-2617 (1971)

$18 \mathrm{R}$ T TAYLOR and $\mathrm{H}$ WEISSBACH, $\mathrm{N}^{5}$-Methyltet rahydrofolate-homocystenne methyl transferases, pp 121-165 in The Enzimes, 3rd Edition (P BOYER, ed )9, Academic Press, New York (1973)

19 L A DECKER, Worthington Enzıme Manual, Worthıngton Biochemical, Freehold, New Jersey (1977) 